\title{
Tarihi İhtilafların Gölgesinde İran-Suudi Arabistan Rekabeti: Şii-Vahhabi İlişkilerinin Dünü ve Bugünü
}

\author{
Mehmet Akif Koç*
}

\section{Öz}

XX. yüzyılın son çeyreğinde tekrar alevlenen ve 2003'te Irak'ın işgalini takiben şiddetlenen İran ile Suudi Arabistan arasındaki, politik ve coğrafi saiklerin de desteklediği mezhepsel görünümlü siyasi ihtilafin güçlü bir tarihi ve kültürel arka planı bulunmaktadır. Bilhassa İran kökenli Büveyhilerin siyasi hâkimiyeti altındaki X-XI. yüzyıllar Bağdat'ında kurumsallaşan İmamiyye Şiiliği, o dönemde şehirde etkin olan Hanbelilerle siyasi nüfuz rekabeti içine girmiştir. Bilahare, Safevilerin bölgede etkinlik kazanması ve ardından XVIII. yüzyılda Vahhabilerin Necd'de güçlenmesiyle, söz konusu nüfuz mücadelesi yeni bir boyuta ulaşmıştır. Günümüzde, Ortadoğu'da yeniden şiddetlenen mezhep motivasyonlu çatışmalar esasen, Dört Halife devri ve Emeviler dönemindeki ayrılıklara ilaveten, XI. yüzyıl başında ve Haçlı Seferleri öncesinde bölgede şekillenen siyasi güç mücadelelerine ve Osmanlı-Safevi rekabetine de dayanmaktadır. Bu tarihsel mücadele, günümüzde de Tahran ile Riyad arasındaki politik mücadele ve bölgesel hegemonya yarışını beslemektedir. $\mathrm{Bu}$ makale, Ortadoğu'nun hâlihazırdaki şiddet sarmalını ve karmaşık ilişkiler ağını daha iyi anlamak için, söz konusu tarihsel dönemleri ve bu dönemlere damga vuran siyasi ve kültürel ihtilafların temel dinamiklerini yakından incelemeyi hedeflemektedir.

Anahtar Kelimeler: Vahhabilik, Şiilik, İran, Suudi Arabistan, Ortadoğu, Bölgesel Rekabet 


\title{
Iran-Saudi Arabia Rivalry in the Shade of Historical Disputes: Past and Present of the Shiite-Wahhabi Relations
}

\author{
Mehmet Akif Koç*
}

\begin{abstract}
The originally political dispute between Iran and Saudi Arabia covered by religious / sectarian explanations re-appeared in the early 1980s after the Iranian Revolution and deepened following the post-2003 US invasion of Iraq. Along with geopolitical ambitions and political-militarily impetus, that dispute also has a strong historical and cultural background. Twelver Shiite (Imamiyyah) School deepened its institutionalism process and experienced a harsh competition for influence with another strong tradition, Hanbali School, in Baghdad which was under the direct political control of Iranian origin Buvayhids. Subsequently, the rise and expansion of another Iranian dynasty, the Safavids, in the region and the ascent of the Wahhabis in Najd added a new dimension to existing political and cultural dispute. Contemporary sectarian violence across the Middle East, in addition to early disagreements and clashes during the rise of Islam and Umayyad era, originates in the regional power politics before the Crusades in the early XIth century and also in the political rivalry between the Ottoman and Safavid Empires. This historical framework further extends current political rivalry based on regional hegemony competition between Tehran and Riyadh. The article aims at reviewing the political and cultural disputes of the periods mentioned above in order to get a better understanding of the fundamental dynamics of current political and sectarian disagreements.
\end{abstract}

Keywords: Wahhabism, Shiism, Iran, Saudi Arabia, Middle East, Regional Rivalry

PhD Candidate, Social Sciences University of Ankara, Middle East Studies, akifkoc@, hotmail.com, ORCID: /0000-0001- 5179-6027 


\section{Giriş}

Ortadoğu'nun son bir asırlık kaotik geçmişi, dış faktörlerin de tesiriyle, şimdiye kadar çok sayıda silahlı/silahsız çatışma ve gerginlik üretmiş olup, öngörülebilir bir gelecekte bu gerginlik ve çatışmaların sona ereceğine dair ümit verici bir perspektif de bulunmamaktadır. Kimi zaman iç dinamikler ve mevcut sınır/toprak ihtilafları bu çatışmaların itici gücü olurken, bazen de var olan gerginlikler doğrudan dış müdahalelerle sıcak çatışmalara evrilmiştir. Bu gerginlikler arasında en tehlikeli olanlar ise, dini ihtilaflara dayanan (veya dayandığı varsayılan) uyuşmazlıklar olmuştur; zira dinin kitleleri harekete geçirme noktasındaki stratejik ve çok boyutlu etkisi, diğer faktörlerden çok daha güçlü ve kalıcıdır. İbrahimî dinlerin (Yahudilik, Hıristiyanlık, İslam) çıkış yeri olan Ortadoğu' da dinin bu negatif ve ayrıştırıcı kullanımı ise, tarihi ve coğrafi dinamiklerin de etkisiyle, diğer pek çok bölgeden daha kanlı sonuçlar üretme potansiyeline sahiptir. Ortadoğu'nun son iki bin yıllık tarihi ve hâlihazırdaki sürekli savaş hali, bu durumu açıça ortaya koymaktadır.

Bölgede gelinen noktada, tamamen özel şartların ürünü olan ve dini ihtilafların beslediği bir siyasi gerginlik olarak, Arap-İsrail çatışması bir kenara bırakılacak olursa; İran ile Suudi Arabistan arasındaki sorunlu ilişkiler, bilhassa son kırk yılda Ortadoğu'nun çözümü en zor ve potansiyel yans1maları en güçlü gerginlik unsuru olarak ön plana çıkmaktadır. Bu sorunlu ilişkinin, tarihteki ihtilafların gölgesinden hâlihazırdaki silahlı çatışma noktasına nasıl evrildiğinin bilinmesi, mevcut gerginliklerin arka planının anlaşılması kadar, gelecekte bu düzlemdeki çatışmaların önlenebilmesi (veya en azından etkilerinin sınırlanabilmesi) açısından da önem taşımaktadir.

$\mathrm{Bu}$ makalede, tarihsel dönemlendirme usulü takip edilerek, günümüzde İran-Suudi Arabistan arasındaki siyasi ve kültürel-dini ihtilafların, ŞiiSünni ilişkilerinin temel dinamikleri ekseninde, tarihsel düzlemdeki sürekliliğinin ortaya konulması amaçlanmaktadır. Bu bağlamda, İslam'ın ilk yüzyıllarından başlayarak üç ayrı dönem temelinde, Şii-Sünni rekabeti ve ihtilafını ortaya çıkaran temel dinamikler ele alınacak, bu ihtilafların mezhepsel görünümünün arka planında yatan siyasi saikler incelenecek, Şii İslam ve Hanbeli (bilahare Vahhabi) İslam yorumlarının birbirleriyle çatışmasındaki değişim ve süreklilik unsurlarına odaklanılacaktır. Çalışmanın akışı içerisinde ilk dönem kaynakların yanısıra, çatışmanın her iki 
tarafının tez ve argümanlarına da imkânlar ölçüsünde yer verilecek, bunlara ilaveten yabancı dildeki kaynak ve analizler de çalışmanın akışı içinde kullanılacaktır.

İlk dönem, Dört Halife devrindeki siyasi ihtilaflardan başlayarak, bilhassa $X$ ve XI. asırlarda Bağdat'ta kristalize olan Şii-Sünni (İmamiyye-Hanbeli) ihtilafını ele alacaktır. İkinci dönem, Osmanlı-Safevi rekabetiyle başlayıp, Vahhabiliğin ortaya çıkmasıyla şiddetlenen bölgesel çatışma dinamiklerine 1şık tutmayı hedeflemektedir. Üçüncü ve son dönem ise, XX ve XXI. yüzyıllarda İran-Suudi Arabistan arasındaki güç mücadelesinin tetiklediği ve 1979 Devrimi’nden sonra yoğunlaşan bölgesel ve uluslararası güç mücadelesinde Şii-Sünni ilişkilerinin rolüne odaklanmaktadır.

\section{2. Şiî-Sünnî Gerginliğinin Tarihsel Kökeni ve Gelişim Süreci}

Şiî-Sünnî ayrılığının geçmişi, Hz. Peygamber'in vefatına (M.632) kadar geri götürülür; ancak bu dönemde ortada cemaatler ve mezhepler bulunmamaktayd1, veraset teorileri de henüz geliştirilmemişti; doğrudan doğruya şura ve uzlaşıyla halefin belirlenmesi kaidesi geçerliydi. ${ }^{1} \mathrm{Bu}$ ilk dönemde en iyimser ihtimalle, 'Ali taraftarlığı' şeklinde oluşmaya başlayan bir gruplaşma hareketinden ${ }^{2}$ söz edilebilir ki bu, mezhep veya cemaat olarak değerlendirilemez. Sıffin Savaşı ve ardından Muaviye öncülüğünde Emevilerin yönetime gelmesiyle, İslam devlet yönetiminde saltanat süreci baş$\operatorname{lad}^{3}$. Bilahare, Abbasilerin İran-Horasan merkezli bir askeri ihtilal yoluyla yönetimi ele geçirmeleri karşısında, ${ }^{4}$ iktidar için diğer tüm gruplardan daha ehil ve layık olduklarını düşünen Şii gruplar (muhalif bir firka olarak), saltanat girişimlerine karşı liderliğin sadece Ehl-i Beyt mensuplarına ait olduğunu savunan 'imamet teorisini' geliştirdiler. ${ }^{5}$

Muhammed b. Abdülkerim b. Ahmed eş-Şehristani, el-Milel ve'n-Nihal (Dinler, Mezhepler ve Felsefi Sistemler Tarihi), trc. Mustafa Öz (İstanbul: Litera Yayıncılık, 2008), 38-39

2 Marshall G.S. Hodgson, "How did the Early Shî'a become Sectarian?”, Journal of the American Oriental Society, 75, No. 1 (Jan. - Mar., 1955): 1-2.

3 Sayyid Muhammad Husayn Tabatabai, Shiite Islam (Albany: State University of New York Press, 1975), 55-57

4 Murtaza Mutahhari, Ehl-i Beyt Imamlarının Siyasi Tutumlarl, trc. Cafer Bendiderya, (İstanbul: Kevser Yayınlar1, 2007), 103-106.

5 Ahmet el-Kâtip, Nedenleri Tarihte Kalmış Siyasi Ayrılık: Sünnilik-Şiilik, trc. Muharrem Tan (İstanbul: Mana Yayınları, 2013), 175-181. 
Abbasilerde merkezi otoritenin zayıflamasıyla birlikte, farklı firka ve etnik kökenlere mensup çok sayıda bölgesel hanedanlık kuruldu. Bu dönemde, İslam coğrafyasının farklı bölgelerinde Şii hanedanlar ve emirlikler de yerel düzeyde kendi siyasi hâkimiyetlerini kurdu. Hatta bazı Batılı araştırmacılar onuncu yüzyılı bir 'Şii asrı' olarak görmektedir, zira bu dönemde Mısır'da Ihşidiler (935-969), Diyarbakır'da Kürtler ve Kuzeybatı İran haricinde İslam dünyası bütünüyle Şii hanedanların yönetimi altındaydı. ${ }^{6}$ Bunlar arasında, hem güç hem de etki alanı açısından iki tanesi özellikle dikkat çekmektedir: Şii İmamlar silsilesindeki Beşinci İmam Cafer esSadık'ın (ö. 148/765) oğlu İsmail'e (ö. 138/755-56 [?]) kendilerini nispet eden Mısır'daki Fatımî Devleti (909-1171) ve İran'ın kuzeyindeki Deylem'de kurulan Zeydi-İmami görüşlü Büveyhi Devleti (945-1055).

Büveyhiler, askeri sahada hızlıca yükselip, kısa sürede Bağdat'ı ele geçirdiler; Selçuklu Sultanı Tuğrul Bey'in (ö. 455/1063) Abbasi Halifesi'nin davetiyle Bağdat'a girdiği 1055 yılına kadar, yaklaşık 110 yıl boyunca Abbasi yönetimine hâkim oldular. Şiiliğin dini temelli bir siyasi çekim merkezi olarak kurulup gelişmesi, dini literatürü ve fikhının olgunlaşması, ritüellerinin belirginleşmesi, Abbasi Halifelerinin merkezi yönetimde güç kaybettikleri ve Büveyhilerin Bağdat'a hâkim olduğu X ve XI. yüzyıllarda hız kazand1. ${ }^{7}$ Hatta bu dönemde Şiiliğin Büveyhi idaresi altında yeniden canlanması ve kurumsallaşması öyle ileri bir düzeye erişti ki Şeyh Sadûk (ö. 381/991), Şeyh Müfîd (ö. 413/1022), Şerîf er-Radî (ö. 406/1015), Şerîf el-Murtazâ (ö. 436/1044-45) ve Ebû Ca'fer et-Tûsî (ö. 460/1067) gibi Şii düşüncesinin oluşum ve gelişiminde çok önemli rolleri olan düşünürler bu rahatlama devrinde yetiştiler. ${ }^{8}$

Bu noktada vurgulanması gereken bir husus da, Şii-İmamî düşüncesinde ilk asırlar itibariyle ana akım yaklaşımı ifade eden Ahbarî ekolün çeşitli sinırlılık ve yetersizlikleri karşısında, akıl ve istidlal metotlarına daha fazla ağırlık vermeyi savunan Usulî ekolün ${ }^{9}$ doğuşunu hazırlayan şartların da

6 Hamilton A.R. Gibb, "The Caliphate and the Arab States" in, A History of the Crusades, ed. M.W. Baldwin (Wisconsin: The University of Wisconsin Press, 1969), 86.

7 Muhammed b. El-Muhtar eş-Şankıtî, Haçlı Seferlerinin Etkisi Altında Sünni - Şii İlişkileri, trc. İdris Çakmak (İstanbul: İlimyurdu Yayıncılık, 2016), 86-93.

8 Harun Yıldız - Ferhat Maden, "Büveyhiler Dönemi Şii Düşünürleri”, e-Makalat Mezhep Araştırmaları Dergisi 10 / 2 (Aralık 2017): 270.

$9 \quad$ Habib Kartaloğlu, "İmamiyye'de Ahbarî-Usulî Farklılaşması: Şeyh Saduk ve Şeyh Müfid Örneği”, Sakarya Üniversitesi Illahiyat Fakültesi Dergisi, XIII, Sayı: 24 (2011/2): 199-200. 
aynı dönem ve coğrafyada ortaya çıkmasıdır. Bu meyanda, dönemin siyasi iktidarının sağladığı rahatlıkla, bilhassa Bağdat'taki Şii-İmamî ulema, söz konusu dönemde etkin olan Mu'tezile ekolünün de tesiri altında, doktrinel esasların mantıki geçerliliklerini ortaya koymaya çalışmıştır. ${ }^{10} \mathrm{Bu}$ anlamda, hem Şii düşünce ve ritüellerin yeniden canlanıp kurumsallaşması, hem de iki ana akım yaklaşımdan Usulî düşüncenin teşekkül süreci, dönemin siyasi otoritesinin Bağdat'ta sağladığı şartlar sayesinde mümkün olabilmiştir.

Tüm bu süreç boyunca, birbirinden farklı yönelimlere sahip Şii Haşimî, Alevî, Hüseynî veya Hasenî akımlar ${ }^{11}$ kendi aralarında sürekli çekişti ve savaşt1. ${ }^{12}$ Sünni siyasal düşüncesi ise 'politize olmaksızın' yaşamaya devam etti; zira pragmatik davranıp, en azından teorik olarak, yöneticinin toplumun fertleri tarafından karşıllıklı rıza (şura) ile seçilmesi gerektiğine inandıkları için, 'zamanın icabâtına göre' hareket etti ${ }^{13}$ ve hükümranlık kuran siyasi oluşumları (Abbasi, Büveyhi, Fatımi, Selçuklu ayrımı yapmadan) büyük bir siyasi kargaşaya yol açmaksızın, meşru otorite olarak kabullendi. ${ }^{14}$ Esasen bu durum, gerçek mücadelenin sanıldığ 1 gibi mezhepler (Sünni-Şii) arasında değil, güç yarışı içine giren siyasal çevreler arasında yaşandığını göstermektedir. ${ }^{15}$ Bununla birlikte, fikri ve fikhî çevreler, sosyal dinamikleri ve kitleleri harekete geçirebilmek için bu ayrılıkları her dönemde istismar etmekten ${ }^{16}$ ve kendi menfaatleri doğrultusunda seferber etmekten de geri durmamışlardır.

10 Habib Kartaloğlu, "Şiî-Usulî Düşüncenin Ortaya Çıkış Sebepleri Üzerine Mülahazalar", Sakarya Üniversitesi İlahiyat Fakültesi Dergisi, XVIII, Say1: 33 (Haziran 2016): 8586.

11 Sa'd b. Abdullah Ebu Halef Kummi el-Eş'ari - Ebu Muhammed Hasan b. Musa Nevbahti, Kitabü'l-Makalat ve'l-Fırak / Fıraku'ş-Şia, trc. Hasan Onat / Sabri Hizmetli / Sönmez Kutlu / Ramazan Şimşek, (Ankara: Ankara Okulu Yayınları, 2004), 90-113.

12 Mehmet Ali Büyükkara, İmamet Mücadelesi ve Haşimoğulları (İstanbul: Rağbet Yayınlar1, 1999), 9-10

13 Ramazan Yıldırım, "Sünni Siyaset Düşüncesinin Tarih İçindeki Gelişimi ve Etkinliğì, İstanbul Üniversitesi Illahiyat Fakültesi Dergisi, (2011): 24; 23

14 İbn Hazm Ebu Muhammed Ali b. Ahmed b. Said b. Hazm, el-Fasl fi'l-Milel ve'l-Ehva' ve'n-Nihal (Dinler ve Mezhepler Tarihi), trc. Halil İbrahim Bulut, (İstanbul: Türkiye Yazma Eserler Kurumu Başkanlığı, 2017), 3: 434-442.

15 Şankıti, Sünni-Şii İlişkileri, 94-95.

16 Ali Muhammed Sallabi, Zengiler Dönemi-İslami İdarenin Yeniden Hâkim Kılınması, trc. Turgut Akyüz (İstanbul: Ravza Yayınları, 2014), 384-385, 463-475. 
Hz. Peygamber'in vefatından sonra benimsenmiş olan ve sınırlı ölçüde / belirli konularda birkaç on yıl uygulama alanı bulabilen şura esas $1,{ }^{17}$ sonraki yüzyıllar içinde ne Sünni ne de Şii siyaset teorileri ve pratiklerinin merkezinde yer alabilmiştir. On iki İmam Şiiliği, XI. İmam Hasan el-Askeri’nin 874 yılında, kendisinden sonra liderliği üstlenecek bir oğul bırakmadan ölmesinin ardından, dinamizm ve gelecek umudunu büyük ölçüde kaybetti. Her ne kadar İmamiyye Şiiliği, gizli bir oğulun varlığını iddia etse ve inanç öğretisinin temeli mahiyetinde kabul edilen bir kısım rivayetlerle bunu, 'Gaib İmam' formunda bir umut habercisi haline getirse de ${ }^{18}$ IX. yüzy1l itibariyle Abbasilere karşı siyasal iddiasını ve güç zeminini yitirdi. Sonraki dönemlerde ise iki güçlü Şii fırkadan/hanedandan Zeydilik, Selçukluların Bağdat'taki Büveyhi hâkimiyetini yıkması sonucu hâkimiyetini kaybetti; ${ }^{19}$ Mısır'daki Fatımilik de Haçlı Seferleri sürecinde Selahaddin Eyyubi tarafindan siyaset sahnesi ve güç oyunundan büyük oranda tasfiye edildi. XII. yüzyılın sonuna gelindiğinde, Şiiliğin en güçlü bu üç firkası (İmamiyye, Zeydiyye, İsmaililik-Fatımiler) bu süreçte Sünni iktidarlar tarafından alternatif olmaktan çıkarılmış, Nizari-İsmaili Şeyhi Hasan Sabbah'ın (ö. 518/1124) kurduğu siyasi yapının da Moğollar tarafından yıkılmasıyla, Şii toplulukları marjinal gruplar halinde ve dağınık olarak varlıklarını güçlükle sürdürebilir olmuşlardı. ${ }^{20}$

Diğer taraftan, Sünni siyasi ve fikri dünyasının da bu dönemde yekpare bir bütün oluşturmadığını vurgulamak gerekmektedir. Bilhassa Abbasiler dönemi şartlarında, Sünnilikteki ana ayrım Eş'ari ve Hanbeli ekolleri arasındaydı. Eş'ariler kutsal metinlerde Allah'a atfedilen hususları maddi olarak yorumlamada daha ihtiyatlı ve senkretik düşünce çizgisini takip ederken; Hanbeliler ise metni anlamada daha lafzi bir tutum sergiliyor, bazıları ise insanbiçimci bir tanrı görüşüne daha yakın duruyordu. Hanbeliler, Abbasi başkenti Bağdat'ta hukuki sistemi kendi kontrollerine almak için yoğun bir çaba içerisinde oldular ve rakiplerine fiziksel olarak da hücum ettiler. ${ }^{21}$

17 Talip Türcan, "Şûra", Türkiye Diyanet Vakfi İslam Ansiklopedisi, (İstanbul: TDV Yayinlar1, 2010): 39:230-235

18 Metin Bozan, İmamiyyenin İmamet Nazariyesinin Teşekkül Süreci, (İstanbul: İSAM Yayınlar1, 2009), 208-217

19 Sallabi, Zengiler Dönemi, 473-475.

20 Farhad Daftary, Şii İslam Tarihi, trc. Ahmet Fethi (İstanbul: Alfa Kitap, 2016), 90-99.

21 Muhyeddin İğde, "Selefiliğin Tarihi Arka Planı", e-Makalat Mezhep Araştırmaları Dergisi 8, No.2 (Nisan 2016): 165-166. 
Büveyhilerin hâkimiyeti altında, sonradan Şiiliğin esas unsurlarından biri haline getirilen ve İmam Hüseyin'in şehadetini yâd etmek için yapılan Aşura törenleri, Büveyhi emiri Muizzüddevle'nin (ö. 356/967) emriyle 963 yılından itibaren resmi hale getirilmeye çalış1ldı. Hanbeliler ise bu uygulamayı 'bidat' olarak gördü ve sert tepki gösterip durdurmaya çalıştı. Şii olduklarını unutmamakla birlikte, Abbasilerle uyumlu bir yönetim ilişkisi geliştiren (Zeydi gelenekten gelen) Büveyhiler, ${ }^{22}$ kendilerini zamanla İmamiyye Şiası içerisinde tanımlamaya başladı ve Sünniler karşısında güç kaybedince, daha önce siyasi saiklerle mesafeli durdukları ve hatta Adudüddevle (ö. 372/983) döneminde savaşın eşiğine geldikleri İsmailî Fatımi Devleti'nden ${ }^{23}$ destek aramaya başladı. ${ }^{24}$

İbn-i Haldun (ö. 808/1406), "Bağdat’ta Şiilerle Sünniler arasında ve Hanbelilerle diğer bütün fikir ekolleri arasında sabit bir çatışma vardı" sözleriyle bu hareketli ihtilaf dönemini tanımlamaktadır. ${ }^{25}$ Bu dönemde Fatımi Devleti'nden ve suikast pratiklerinden dolayı daha fazla tepki gösterilen İsmaililere nazaran, On iki İmam Şiilerine özellikle Eş'arilerce daha mutedil yaklaşıldı, buna karşılık Hanbeliler her türlü Şii akımlara sert davrandı. Bağdat'taki en kalabalık iki cemaat olan Hanbeliler ve Şiiler arasında sürekli bir çatışma durumu yaşand ${ }^{26}{ }^{26}$ Dönemin siyasi ve kültürel şartlarında en önemli merkez konumundaki Bağdat'ta yaşananlar çevreye de tesir etti, Suriye ve Mısır'da birçok siyasi ve mezhepsel çatışmanın da arka planı Bağdat'taki ayrışmada kaynak buldu. Aynı dönemde Hanefi geleneğe mensup Sünnilerle Şiiler arasındaki dini ve siyasi ihtilafların oldukça az oluşu da bu açıdan dikkat çekmektedir. ${ }^{27}$ Esasen, günümüzde Şiilerle dini ve siyasi düzlemde en sorunlu Sünni ekolün, Selefi ve Vahhabi cereyanların bağrından neşet ettiği Hanbelilik olması, yaklaşık bin yıl önce Bağdat'ta gerçekleşen fikri ve siyasi ayrışmaların büyük oranda XXI. yüzyıla yansıması niteliğindedir.

\footnotetext{
22 Ahmet Güner, Büveyhilerin Sii-Sünni Siyaseti, (İzmir: Tibyan Yayıncılık, 1999), 95.

23 Ahmet Güner ve Mehmet Azimli, "Büveyhiler: Abbasiler'in Başkenti Bağdat’ta Hüküm Süren İran Kökenli Şii Bir Hanedan”, İslam Tarihi ve Medeniyeti Külliyatl, Cilt 7 (Abbasiler Döneminde Kurulan Devletler), ed. İsmail Hakk1 Atçeken ve Mustafa Demirci, (İstanbul: Siyer Yayınları, 2018).

24 Şankıti, Sünni-Şii İlişkileri, 93-98.

25 Ibn Khaldun, Tarikh Ibn Khaldun, (Beirut: Dar Al-Qalam, 1984), 3: 662.

26 Abd al-Rahman Ibn al-Jawzi, al-Muntazam fi Tarikh al-Mulûk ve'l-Umem, (Beyrut: Dar Şadir, 1939), 7: 283; 8: 45-47, 141-142

27 Şankıti, Sünni-Şii İlişkileri, 94-96.
} 
Ancak bu dönemde Sünni egemenliği de çok ciddi bir darbe almış olup Moğollar, Abbasi Hilafeti'ni XIII. yüzyıl ortasında tarih sahnesinden silince, Mısır'daki Memluklar sembolik hale gelen Abbasi Halifeliği'ne kucak açmıştır. Hanefi ekolün, siyasi yönetim için sınırları kesin olarak belirtilmiş bir kuralı öngörmemesi ve halifeler için 'Kureyş kabilesine mensup olmayı' şart koşmaması, bir süre sonra bu sembolik makamın Memluklardan Osmanlılara geçişine zemin hazırlamıştır. Ancak, İslam'ın ilk birkaç asrındaki büyük topraklara hükmeden ve İslam dünyasının neredeyse bütününü hâkimiyeti altında cem eden halifelik kurumu bir daha bu ölçüde büyüklüğe ulaşamamıştır. Esasen, Moğolların Bağdat'ı almasıyla, İslam dünyasında artık güçlü merkezi imparatorluklar devri başlamıştır. Bu yeni imparatorlular çağında, Ortadoğu hâkimiyetinde bayrağı Sünni Memluklardan devralan Osmanlılar, Irak ve Doğu Anadolu/Kafkasya hâkimiyeti için XVI. yüzyılın başından itibaren karşılarında yine güçlü bir merkezi imparatorluk bulmuştur: Bu da İran kökenli bir Türkmen hanedan olan ve Anadolu'da da kendine ciddi bir taban bulabilen Safevilerdir.

Başlangıç itibariyle Sünni bir tasavvuf yolu olan Erdebil tekkesinin devletleşmesiyle ortaya çıan Safeviler, çevresindeki Sünni kökenli güç merkezleriyle siyasi ve jeopolitik güç mücadelesinde, On iki İmam firkasını bir tür kalkan olarak kullanmış; ancak bunu yaparken, Şii doktrindeki Masum Imam yönetimi sorunu ve gaybet devrinde hükümet kurmanın meşruiyetinin olmaması prensiplerinin fikhi olarak etrafından dolanmış, bu hükümleri kendilerine göre yorumlamışlard1. ${ }^{28} \mathrm{Bu}$ döneme kadar, Haçlı Seferleri, Moğolların yıkımı gibi büyük tarihsel travmaların da etkisiyle neredeyse unutulmaya ve en azından siyasi gündemden düşmeye başlayan Şî̂-Sünnî ihtilafı, ${ }^{29}$ Safevi-Osmanlı rekabeti ve özellikle Irak coğrafyası üzerindeki güç mücadeleleri sonucu yeniden siyaseten kullanıma sokulmaya başlandı. Safeviler, her ne kadar XVIII. asrın başlarında Afgan saldırıları sonucu yıkılsa da hâkimiyetleri döneminde İran'ın tamamen Şiileştirilmesini sağlamalarının yanı sıra, İmamet teorisini devrin şartlarına uyarlayarak, Ortadoğu Şiileri için İran'1 yeni bir çekim merkezi haline getirdiler. ${ }^{30}$

28 Seyyed Hossein Nasr, Islam - Religion, History, and Civilization, (New York: Harper Collins Publishers, 2003), 132-133

29 Tabatabai, Shiite Islam, 84

30 Ali Şeriati, Ali Şiası Safevi Şiası, trc. Hicabi Kırlangıç, (Ankara: Fecr Yayınevi, 2009), $44-54$ 
Buna mukabil İstanbul'daki din adamlarının, esasen her devrin kronik sorunu olan, dini siyasetin emrine vermelerinin de bir sonucu olarak Şia'y1 bu dönemde tamamen düşman olarak yansıtıp, dindışı ilan etmeleri ve tarihin derinliklerinden doğan ötekileştirici düşmanlık argümanlarının iki tarafça da bolca kullanıma sokulması, ${ }^{31}$ Şiî-Sünnî ihtilafinın küllerinden doğarak modern zamanlara taşınmasına zemin hazırladı.

\section{3. Şiiliğin İran Coğrafyası ve Kültürüyle İlişkisi}

Arap-İslam ordularının 633-654 yılları arasında sürekli yaptığı seferler ve zorlu mücadeleler sonucu Sasani İmparatorluğu'nun yıkılmasıyla, İslamiyet, İran'da yayılabilecek geniş bir zemin elde etti. Bununla birlikte, bir dönem antik dünyanın en önemli imparatorluklarını kurmuş olan zengin İran kültürünün, bir anda İslamiyet'e girdiğini ve yeni dine sorunsuz bir şekilde teslim olduğunu düşünmek yanıltıcıdır. ${ }^{32}$ Bilhassa Emeviler döneminde, Arap olmayan topluluklara karşı tatbik olunan ırkçı yaklaşım ve uygulanan ağır vergiler, Arap olmayan Müslümanlar (mevali) arasında hoşnutsuzlukları artırdı; bilhassa eski Sasani mülkü olan hilafetin doğu topraklarında bir kısım Şii topluluklar ve çoğunlukla proto-Zerdüştçü / Mazdekî kökenli İranlıların güçlü direnişiyle karşıland1. ${ }^{33}$ Nitekim Emevileri yıkan isyanlar silsilesi de İran'ın Horasan bölgesinde zemin bulup güçlendi ve sürecin nihayetinde Abbasiler, tüm bu grupların bir koalisyonu mahiyetinde, Bağdat'ta hükümranlığını ilan etti.

Bu kaotik süreçte, Arap fikri ve siyasi çevrelerinde de ilk dönem İslam düşünce ve pratiğinde bulunmayan, ancak sonradan dine girmiş bazı inanç ve uygulamaların İran menşeli olduğu/olabileceği yönünde yaklaşımlar gelişti. Özellikle, yukarıda değinilen ihtilafların yaşandığı X-XII. yüzyıllarda, Şiiliğin ve aykırı görüşlere sahip bazı alt firkalarının 'aşırı ve bidat' olarak nitelendirilen inançlarının (Gulat) doğrudan İran kaynaklı olduğuna dair

31 Hasan Onat, "XVIII. Asırda Sünni- Şii İttifak Arayışları Üzerine”, erişim: 27 Şubat 2019, http://www.hasanonat.net/index.php/93-xviii-as-rda-suenni-sii-ittifak-arayslar-uezerine\# ; Mehmet Çelenk, Safeviler Döneminin Şii-Sünni İlişkileri Üzerindeki Etkisi, e-Makalât Mezhep Araştırmaları Dergisi VI/2 (Güz 2013), 63-85

32 Ali Şeriati, İran ve İslam, trc. Kenan Çamurcu (Ankara: Fecr Yayınevi, 2012), 55-57

33 Mehmet Azimli, Babek: Bir Direnişçi, (Konya: Çizgi Kitabevi, 2013), 33-74; Gene R. Garthwaite, İran Tarihi: Pers İmparatorluğundan Günümüze, trc. Fethi Aytuna (İstanbul: İnk1lap Kitabevi, 2011), 111-116 
görüşler, sadece Sünni yazarlar değil, bizzat Şii/İmamî âlimler tarafindan da ileri sürüldü. ${ }^{34}$ XIX ve XX. yüzylllarda artan antropolojik ve kültürel çalışmalarla, Şiiliğin İran kökenleri üzerinde daha fazla durulmaya, İranl1ların Şiiliğe girmesinin arka planında bu mezhebin Araplara karşı bir nevi İran'ın milli ruhunu yansıttığı ve İran'ın İslam anlayışını ortaya koyduğu şeklindeki tezler daha da revaç bulmaya başladı. Bu cümleden olarak, Reinhardt Dozy, de Vaux, van Vloten, Edward Browne, Brockelmann, Montgomery Watt, Ebu Zehra gibi düşünür ve araştırmacılara göre;

“-Şia ile İslam öncesi İran din ve kültürleri, özellikle Zerdüştlük arasında önemli benzerlikler vardır. Sasaniler yıkılınca İranlılar İslam'1 seçtiler. Ehl-i Beyt'e sevgi duyan İranlılar eski geleneklerini Şia'ya taşıyarak ona İranî bir şekil verdiler.

-Hz. Hüseyin'in (ö. 61/680) Sasaniler'in son hükümdarı III. Yezdigird'in kızı Şehribanu ile evlenmesi, Arap Şiilerle İranlılar arasında yakınlık ve akrabalık bağı oluşturdu.

-İranlılar, İslam'1 gönül rızası ile değil zorunlu olarak kabul ettiler. Bu nedenle İslam'ı içlerine sindiremediler. Siyasal süreçlerde de tercihlerini İslam içindeki iktidara muhalif kesimlerden Şia yönünde kullanarak, Araplara karşı intikam duygularını tatmin ediyorlardı.

-İran asıllı bazı kişiler Müslüman olduktan sonra yaptıkları ilmi ve siyasi faaliyetlerle, eski dinlerine ait bazı inanç ve uygulamaları İslam'a aktardılar.

-Karakteristik olarak, Araplar özgürlüğü, İranlılar teslimiyetçi köleliği tercih eder, bu nedenle Şii düşünce mutlakıyete ve despotizme sevk eder. Seçim İranlılarda tarih boyunca alışılmadık bir yöntemdi. Siyaseten veraset temelli bir yönetim anlayışına sahip oldukları için, Hz. Ali'nin halife olması ve halifeliği kendisinden sonra çocuklarına bırakması gerektiğini düşünüyorlardı. Bir kısmı bununla da yetinmeyip eskiden hükümdarlarına atfettikleri ulûhiyet düşüncesini Hz. Ali ve evladına da naklettiler." ${ }^{35}$

Bununla birlikte, bazı araştırmacı ve tarihçilerse, Şiiliğin Arap kökenli olduğunu, İran kökenli fikirler henüz etkili değilken ilk olarak Araplar ara-

34 Kummî-Nevbahtî, Kitabü'l-Makalat ve'l-Firak/Fıraku'ş-Şia.

35 Fatih Topaloğlu, "Şia'nın Oluşumunda İran Kültürünün Etkisi”" (Yayınlanmamış Doktora Tezi, Dokuz Eylül Üniversitesi Sosyal Bilimler Enstitüsü Temel İslam Bilimleri Anabilim Dalı, 2010), 20-24 
sında ortaya çıktığını, ilk Şiilerin istisnalar haricinde Arap asıllı olduğunu, İran'ın uzun yıllar Sünni çoğunluğa sahip bir ülke olarak Safeviler dönemiyle birlikte Şiileştirildiğini savunmaktadır. Philippe Hitti, Wellhausen ve Margoliouth gibi bazı müsteşrikler ise, Şii inanç ve ritüellerinde (bilhassa Mehdilik, Aşura, monarşik peygamber düşüncesi, kutsal ailenin yüceltilmesi vb hususlarda) Yahudi ve Hıristiyan tesirleri de aramaktadır. ${ }^{36}$

Yukarıda aktarılan ve İran coğrafyasının İslam ve özelde Şiilik ile ilişkisini ortaya koyan bu görüşlerin iki açıdan sorunlu olduğu düşünülmektedir. Öncelikle bu yaklaşım, Said'in (1977) ayrıntılı bir şekilde vurguladığı üzere ${ }^{37}$ taraflı, tepeden bakan ve önyargılı bir Batılı arka planı yansıtmakta, bu yönüyle indirgemeci ve fazlasıyla genellemeci Oryantalist paradigmanın dışına çıkamamaktadır. İkinci olarak, bilhassa 1979 İran Devrimi’nden sonra, Tahran'ın Batı'yla ilişkilerde yaşadığı gerginlik ve İran İslam Cumhuriyeti'ne yönelik olumsuz politik bakış açısı, akademik çevrelerdeki bu önyargılı tutumdan beslenmekte ve ilaveten, karş11klı etkileşim içinde bu tutumlar birbirini beslemektedir. Özellikle, İran siyasi düşünce geleneğinin 'mutlakiyetçiliği ve despotizmi teşvik edici' karakterine yapılan vurgu, bu sorunlu bakışı göstermesi ve 1979 Devrimi sonrası İran rejimine yönelik hasmane politikanın meşruiyet kaynakları bağlamında dikkat çekmektedir.

Öte yandan, ilk dönem İslam-Arap kaynaklarında İran coğrafyası ve İran'ın siyasi-dini hususiyetlerine yapılan ve günümüzdeki rekabet-ihtilaf dinamiklerini besleyen olumsuz atıflar da yukarıda aktarılan görüşler bağlamında gözönünde bulundurulması gereken bir arka plan sunmaktadır. Keza, Hz. Hüseyin-Şehribanu rivayeti ve Sasaniler-Şiilik bağlamındaki yakınlaştırıcı/meşrulaştırıcı yorumlarda da benzer bir eleştirel perspektifin gözönünde bulundurulması ve geriye dönük tarih inşa etme gayretiyle hareket edildiğinin hatırda tutulması elzemdir.

\section{Vahhabilik ve Şia Karşıtı Konumu}

Sünniliğin Hanbeli kolu içerisindeki Selefiliğin en sert yorumu olarak kabul edilen Vahhabilik, köken itibariyle Arap Yarımadası'nın orta böl-

36 Julius Wellhausen, İslamiyet'in İlk Devrinde Dini - Siyasi Muhalefet Partileri, trc. Fikret Iş1ltan (Ankara: Türk Tarih Kurumu Yayınevi, 1996),148-153; Topaloğlu, İran Kültürünün Etkisi, 25-28, 135-136

37 Edward Said, Orientalism, (London: Penguin Books, 1977), 329-354 
gesindeki çöllerde yer alan Necd'e dayanmaktadır. Bu bölgenin bedevi kabileleri, yaşadıkları çevrenin sert çöl koşulları ve kendi izole şartlarında sahip oldukları katı ve tutucu geleneklerini zaman içinde İslam diniyle harmanlayarak günümüze kadar getirmişlerdir. ${ }^{38}$ F1tratları itibariyle kaba ve mücadeleci olan Arap Bedeviler, İslam'ın ilk dönemlerinde dine 1sınd1rılmış ve pagan inançlarını ${ }^{39}$ terk etmişlerdi. Bilahare, Hz. Ali - Muaviye ihtilafında tamamen kendine özgü bir yorum olarak ortaya çıkan Hariciler de aynı bölgenin savaşçı bedevi kabileleri arasından neşet etmiştir. Zaman içinde bölünerek ve tasfiyelere uğrayarak tarih sahnesinden geri çekilen bu kabileler, XVIII. yüzyılın buhranlı şartlarında Osmanlı merkezi idaresine isyan etmiş, yerel bir güç odağı olarak temayüz eden Vahhabileri de kendi bünyesinden çıkartmıştır. ${ }^{40}$

Özünde reformcu bir hareket olan ve dine sonradan sokulan inanç / ritüellerin (bidat) atılarak, temel kaynaklara/Seleflerin dini anlayışına dönülmesini savunan Selefi/Vahhabi akım için, zamanında Hariciler gibi marjinal / radikal cereyanları bağrından çıkartan Orta Arabistan çölleri münbit bir potansiyel barındırmaktaydı. Buradaki Bedevi kabilelerin desteğiyle güçlenen Muhammed bin Abdülvahhab (ö. 1206/1792) önderliğindeki güçler, 1773 'te Riyad'1 ele geçirdikten sonra, Abdülaziz bin Muhammed bin Suud (ö. 1218/1803) idaresinde 1802'de ciddi bir Şii katliamı gerçekleştirip Kerbela'ya hâkim oldu. Bir süre gelişmelere ilgisiz kalan Osmanlı Devleti, 1803'te Mekke'nin de işgal edilmesi üzerine duruma müdahale etti ve isyanı bastırd1. Vahhabi gelenek, 1932'de Suudi Arabistan'in kurulması sürecinde Kral Abdülaziz bin Suud'la (1880-1953) birlikte hareket etti, günümüzde de süren dini ve siyasi içerikli Suudi-Vahhabi ittifakının modern döneme ait temelleri bu dönemde atıldı. ${ }^{41}$

38 Deniz Yıldırım, “Ortadoğu'da Vahhabi-Şii Mücadelesi”, TESAM Akademi Dergisi,. 5, No.1 (Ocak 2018): 67-69.

39 Cahiliye dönemi Araplarının pagan inançlarının kökenleri ve muhtevası konusunda bkz. W.M. Watt, Muhammad's Mecca: History in the Qur'an, (Edinburgh: Edinburgh Univ. Press, 1988), 29-31; Javier Teixidor, The Pagan God: Popular Religion in the Greco-Roman Near East, (New Jersey: Princeton University Press, 1977); M. Mahfuz Söylemez, "İlk Dönem İslam Tarihi Kaynaklarına Göre Cahiliye Araplarında Ahiret İnanc1", Milel ve Nihal, 13 (1), 2016; 71-109

40 Yaroslav Trofimov, 1979 Kâbe Baskını: Kutsal Mekânda Ayaklanma, trc. Özlem Özarpacı (İstanbul: İyidüşün Yayınları, 2016), 20-23

${ }_{41}$ Natana J. DeLong-Bas, Wahhabi Islam - From Revival and Reform to Global Jihad (London: I.B. Tauris, 2007), 17-19; Y1ldırım, Vahhabi-Şii Mücadelesi, 68. 
İtikat konularında 'Selefi', amelde 'Hanbeli', uygulamada ve mizaç aç1sından 'Harici' olarak tanımlanan Vahhabilik, 'Bedevi ruhu' üzerine ikame edilen bir yaklaşım olduğu için son derece tutucu, radikal ve münferit bir ekol olup, kendisi gibi düşünmeyenleri tekfir etmekte herhangi bir tereddüt göstermemektedir. Bu yönüyle ilk dönem Haricilerini anımsatan Vahhabilik, ötekileştirici ve tekfir edici kimliğiyle, Şii düşünce ve gruplara düşman olduğu kadar, inanç ve pratik açısından Sünni dünya içerisinde de yayılma imkânı bulamamış ve ortaya çıktığı koşullara mahsus bir inanç bütünü olarak kalmış durumdadır. ${ }^{42}$

Yukarıda değinildiği üzere, Abbasiler dönemindeki ihtilaflarla, Hanbeliİmamiyye Şiası çatışması şeklini alan iki taraflı gerginlik, İlhanlılar döneminde İbn Teymiyye'nin (ö.728/1328) öğretileriyle farklı bir boyuta taşınd. Moğolların önünden kaçan ailesinin yerleştiği Suriye'de doğan İbn Teymiyye, Irak'ta zayıflayan Hanbeli itikadını Suriye'de dirilten kişi olarak da bilinmektedir. Döneminin sunduğu siyasî şartlar altında daha sert bir yaklaşım benimseyen İbn Teymiyye, hem gayrimüslimler hem de İslam içindeki 'sapkınlar' nezdinde Sünniliğin en katı savunucularından biri haline geldi. Onun Sünni düşünceye zerk ettiği yoğun Şii karşıtllğı, sonraki dönemlerde önemli bir paradigma değişikliği meydana getirdi. Bu bağlamda, İbn Teymiyye'nin Şiilik karşıtı görüşlerini modern zamanlara aktarmada, ölümünden beş asır sonra ortaya çıkan İbn Abdülvahhab'ın katı yaklaşımı ciddi bir etki doğurdu. ${ }^{43}$ Hanefi-Maturidi çizgiyi benimseyen Osmanlıların askeri-siyasi hâkimiyetinden dolayı, neşet ettiği coğrafyada dahi uzunca bir dönem etkisi düşük kalan Hanbeli ekolü, Vahhabilerin ortaya çıkışları sonrasında yeniden güç kazandı ve XX. yüzyılın ilk yarısında ilan edilen Suudi Arabistan Krallığı'nın resmi mezhebi haline gelerek, ${ }^{44}$ bölgede yeni bir yayılma alanı ve nüfuz imkânı buldu.

Bu yönüyle, hem Vahhabi cereyanının hem de Şiiliğin modern yorumunun, uzun ve sorunlu tarihsel arka plan baki olmak üzere, bilhassa son iki asırda, birbirinin varlığından beslendiğini ve siyasi sahnede bir tez-antitez haline dönüştügünü söylemek mümkündür. Bu bağlamda, hadis temelli bazı rivayet ve referanslar, her iki tarafça diğerini dinen itham ve ilzam etmek

\footnotetext{
42 Y1ldırım, Vahhabi-Şii Mücadelesi, 69-70.

43 Şank1tî, Sünni-Şii İlişkileri, 191-192.

44 İğde, "Selefiliğin Tarihi Arka Planı", 172.
} 
için sıklıkla kullanılmakta olup, en sık kullanılan dini referanslardan biri 'firka-i nâciye' rivayetidir. ${ }^{45}$ İmamet teorisine getirdiği reddiye ve reformcu görüşleriyle tanınan, Şî̂-Sünnî yakınlaşması üzerine çalışmalar yapan, Ahmed el-Katip; hemen hemen tüm İslam firka ve mezheplerinin totaliter nitelikli olduklarını ve çoksesliliğe izin veren demokratik hoşgörü ruhundan mahrum bulunduklarını, her firkanın yalnız kendisinin kurtuluşa eren yol olduğuna (fırka-i nâciye) yönelik ısrarının, mezhep ve firkalar arasındaki mevcut uçurumu daha da açmakta olduğunu savunmaktadır. ${ }^{46}$

\section{XX. Yüzyılda Şiî-Sünnî İhtilafi ve İran-Suudi Arabistan İlişkileri}

Dini ve tarihi nitelikli bu yapısal problemlere ilaveten, eski ve köhnemiş imparatorlukların yerine modern dönemlerde kurulan yeni rejimlerin de çoğunlukla, siyasal anlamda otoriter karaktere sahip olmaları nedeniyle, iktidarın pekiştirilmesi için eski düşmanlıklar ve var olan mezhebi farklılıklara yaptıkları vurgu daha da artmış durumdadır. Bu bağlamda, ilk yüzyıllarda yaşanan teolojik ve fikri ayrılıkların, sonraki yüzyıllarda bu ayrımları derinleştiren imparatorluklar arası savaş ve bölgesel rekabet safhasının ardından, modern dönemde devletler arası güç mücadelesinin birer meşrulaştırıcı unsuruna dönüştügü görülmektedir. Bu açıdan, bu çalışmaya rengini veren dönemselleştirme perspektifi açısından, ilk iki tarihsel safhayı takiben, XX. yüzyılda başlayan ve XXI. yüzyılda daha da şiddetlenen bölgesel güç mücadelesinin üçüncü safhayı oluşturduğu söylenebilecektir.

Hâlihazırdaki uluslararası sistem ve bölgesel şartlarda, söz konusu İranSuudi Arabistan güç mücadelesini açıklamak için hem Realist hem Konstrüktivist temelli açıklamalar birbirini tamamlayan genel bir çerçeve sunmaktadır. Bu kapsamda mevcut bölgesel anarşi ortamında ${ }^{47}$ iki ülkenin güç mücadelesi açısından, Neo-realist yaklaşımla, her türlü değer ve unsur 'güç' kavramının bir bileşeni olarak algılanmakta; diğer taraftan, Konstrüktivist yaklaşımın önerdiği şekliyle de, sahip olunan kültürel öğeler ve

45 Mevlüt Özler, İslâm Düşüncesinde 73 Fırka Kavramı, (İstanbul: Nûn Yayınları, 1996), 65-103.

46 Kâtip, Sünnilik - Şiilik, 263-264.

47 Raymond Hinnebusch, "Foreign Policy in the Middle East," The Foreign Policies of Middle East States, Raymond Hinnebusch - Anoushiravan Ehteshami (Eds.), (Boulder: Lynne Reinner, 2014), 1-34 
kimlikler dış politikada rakip devletlere/güçlere karşı araçsallaştırılmaktadır. Nitekim bu bölümde ele alınacak ülke ve bölge bazlı ihtilaf alanlarında, bahsekonu Realist ve Konstrüktivist argümanların sahada kullanımına geniş bir şekilde atıfta bulunulacaktır.

Kökleri Ortadoğu tarihinin uzak geçmişinde kalan Şiî-Sünnî ihtilafı bölge ülkeleri tarafından bilhassa son yüzyıl içinde yeniden kullanıma sokulmuş durumdadır. 1979 Devrimi sonrasında İran'da İmamiyye Şiası'nın güçlü bir şekilde iktidarı ele geçirmesi, bunun akabinde Irak'la uzun süren ve yüz binlerce insanın hayatını kaybettiği kanlı bir ölüm kalım savaşına girilmesi sürecinde, söz konusu tarihi argümanların siyasetçilerin elinde nasıl tehlikeli ve dışlayıcı şekilde kullanıldığına yakinen şahit olunmuştur. Benzer şekilde, Arap Baharı sürecinde ve özellikle Suriye İç Savaşı boyunca, bölgede başta İran ve Suudi Arabistan olmak üzere, hemen her seviyedeki Şii veya Vahhabi/Selefi eğilimli siyasi ve dini liderler 'öteki’ olarak gördükleri birbirlerine yönelik olarak bu argümanlara sıklıkla müracaat etmiş olup, hâlihazırda bu söylemi büyük bir kararlılıkla sürdürmektedirler. ${ }^{48} \mathrm{XX}$. yüzyılda İran-Suudi Arabistan ilişkilerinin (ve dolayısıyla modern dönem Şiî-Sünnî/Imami-Hanbeli ihtilafının) geçmişine bakıldığında, bölgesel gelişmeler ve konjonktürün de etkisiyle, birbiri içine geçen yakınlaşma-gerginlik sarmalları dikkati çekmektedir.

Tahran-Riyad ilişkileri, XX. yüzyılın büyük bölümünde var olan çeşitli gerginlik unsurlarına rağmen, 1979 Devrimi'ne kadar büyük ölçüde barışç1 ve dostane havada sürdürüldü. 1929 tarihli dostluk anlaşmasının ardından, iki taraf arasında diplomatik ilişkiler kuruldu, ancak 1960'lara kadar ilişkilerde önemli bir gelişme yaşanmadı. 1965 yılında Suudi Kralı Faysal'ın İran'1 ziyaretiyle ilişkilerde ivmelenme başladı, Faysal'ın 1967'deki ikinci Tahran ziyaretinin ardından, Şah Muhammed Rıza Pehlevi de 1968'de Riyad'a mukabil ziyarette bulundu. Bu dönemde, İran Şahı'nın İsrail'i tanıma kararı ve Suudilerin öncülük ettiği (Arap-İsrail savaşlarından dolayı) 1973 Petrol Boykotuna İran'ın katılmaması ikili ilişkilerde rahatsızlık oluşturdu. ${ }^{49}$ Körfez'deki üç adanın (Büyük Tunb, Küçük Tunb ve Ebu

48 Ahmet Yönem, “Şii-Sünni İlişkileri Bağlamında Günümüz Selefiliğì”, Ortadoğu'nun Geleceği Açısından Şii-Sünni İlişkileri Sempozyumu Bildirileri (Çorum, 27-29 Eylül 2013), ed. Mesut Okumuş - Cemil Hakyemez (Ankara: Çorum Belediyesi Kültür Yayınlar1, 2014), 135-136.

49 Henner Fürtig, Iran's Rivalry with Saudi Arabia Between the Gulf Wars (Reading: Ithaca Press, 2002), 2-17 
Musa) aidiyeti sorununun BAE ile İran arasında ihtilafa konu olması da ikili ilişkilerde dönem dönem sorunlar doğurdu. ${ }^{50}$ Buna rağmen TahranRiyad ilişkileri Devrim'e kadar, çatışmasız ve genellikle istikrarlı bir atmosferde yürütüldü.

Bu görece istikrarlı ilişkilerin temelinde, ABD'nin Nixon-Kissinger Doktrinine uygun olarak hazırladığı 'Çifte Sütun Politikası' uyarınca (Twin Pillar Policy), bölgede oluşturulması planlanan güvenlik sisteminin iki önemli sacayağının İran ve Suudi Arabistan üzerine kurulması stratejisinin rolü büyüktür. Bu plan uyarınca, Tahran-Riyad ilişkilerinin yakınlaştırılması, İran'ın askeri açıdan, Suudi Arabistan'ın ise mali ve ekonomik güç olarak bölgede konumlanması öngörülmüştü. ${ }^{51} \mathrm{Bu}$ yakın ilişkilerin belki de en büyük göstergesi, Kral Faysal'ın 1969 Eylül ayında İslam ülkeleri liderlerini Rabat'ta bir araya getirmesi ve akabinde İslam Konferansı Teşkilatı'nın kurulmasına öncülük etmesine İran Şahı'nın verdiği destekti. Bunda her iki ülkenin de Soğuk Savaş şartlarında aynı kampta yer almaları ve (İsrail ve Türkiye'yle birlikte) ABD'nin bölgedeki en önemli müttefikleri arasında bulunmaları da belirleyici rol oynadı. Bu süreçte, Nasır ve Baas öncülügündeki Arap milliyetçiliği akımıyla, Arap monarşileri arasında yaşanan 'Arap Soğuk Savaşı' da Tahran-Riyad ilişkilerindeki yakınlaşmanın arka planındaki önemli dinamiklerden birini oluşturmaktadır. ${ }^{52}$

1979 İran Devrimi, Tahran-Riyad hattındaki iyi komşuluk ve dostane ilişkiler üzerinde çok ciddi bir kırılma meydana getirdi ve yeni krizlerin kapısını açtı. 1979'dan sonra İran liderliğinin 'devrimi diğer İslami topluluklara da ulaştırma' hedefi koyması; Suudi Arabistan'ın petrol zengini doğu vilayetlerinde yaşayan Şii azınlık kadar, Riyad'ın etki alanı olarak gördüğü Körfez Bölgesi, Irak gibi Şii toplulukların yoğun olarak yaşadıkları yerlerde de Sünni yönetimler açısından varoluşsal bir tehdit olarak algılandı. Bu ülkelerde İran'la bağlantılı hak talebi ve başkaldırı hareketleri sert bir şekilde bastırıldı. Bu yakın tehdit algılamasının bir sonucu olarak, Devrimin hemen ardından başlayan İran-Irak Savaşı (1980-88) sırasında,

50 Faisal bin Salman al-Saud, Iran, Saudi Arabia and the Gulf: Power Politics in Transition (London: I.B. Tauris, 2003), 8-9.

51 İzzetullah İzzeti, İran ve Bölge Jeopolitiği, trc. Hakkı Uygur (İstanbul: Küre Yayınları, 2005), 78-79.

52 Banafsheh Keynoush, Saudi Arabia and Iran: Friends or Foes? (New York: Palgrave Macmillan, 2016), 85-86, 71-73. 
Riyad, ABD'nin de desteğiyle, Saddam Hüseyin'in en önemli finansal destekçisi ve silah tedarikçilerinden biri oldu. ${ }^{53}$ Keza, 1980'lerin başında Suudi Arabistan'ın öncülüğünde kurulan ve Körfez'deki küçük Arap monarşilerini/şeyhliklerini bir araya getiren Körfez İşbirliği Konseyi (KİK) de İran'dan algılanan güvenlik tehdidine cevap niteliğindeydi. ${ }^{54}$

1987 Hac döneminde, İranlı hacıların Mekke sokaklarındaki yürüyüşü ve protestoları sırasında saldırıya uğrayıp, yüzlercesinin Suudi yetkililerce öldürülmesi, ilişkilere 1980'lerin gerilimli yıllarını tamamlayan dini bir motif ekledi. Tarihteki Şî̂-Sünnî (daha doğrusu İmami-Hanbeli) ihtilafını yeniden dirilten slogan ve ritüeller ise savaş döneminde her iki tarafça da sıklıkla kullanıld. ${ }^{55} \mathrm{Bu}$ gerginlik döneminin ardından, 1989'da Devrimin Lideri Ayetullah Humeyni'nin ölmesiyle birlikte daha fazla manevra alanı bulan, 1lımlı ve pragmatik kişilikli Haşimi Rafsancani'nin Cumhurbaşkanlığ1 döneminde (1989-1997), Tahran-Riyad hattında yoğun bir diplomatik trafik yaşandı. Kazablanka'daki ilk temaslar Riyad'a taşındı, yıllar süren kapalı müzakerelerde ikili ve bölgesel sorunlar masaya yatırıldı. Bu temaslar sonuç verdi ve 1997'de Veliaht Prens Abdullah bin Abdülaziz Tahran'1 ziyaret etti, ardından Rafsancani 1998'de, Devrim sonrası bu ülkeyi ziyaret eden ilk İranlı lider sıfatıyla, Suudi Arabistan'a gitti (Rafsancani'nin o dönem yardımcısı olan, bugünün Cumhurbaşkanı Hasan Ruhani de ziyaret sirasında kendisine refakat etmekteydi). Rafsancani'nin halefi, reformcu kanattan Muhammed Hatemi döneminde de ikili ilişkilerdeki yakınlaşma trendi sürdürüldü. 2001'de iki ülke arasında imzalanan güvenlik ve işbirliği anlaşması, sürecin rayında gittiğinin bir işareti olarak değerlendiriliyordu. ${ }^{56}$ Cumhurbaşkanı Ahmedinejad'ın 2007'deki Riyad ziyareti, 1990'larda yakalanan ivmenin şeklen de olsa devam ettiğini düşündürmekteydi; ancak müteakip birkaç yıl içerisinde ikili ilişkiler modern dönemin en kötü seviyesine gerilemiş durumdadır.

Günümüzde sıcak çatışmaya doğru hızla ilerlemekte olan İran-Suudi Arabistan ilişkilerinde, tarihsel ve jeopolitik dinamiklerin olumsuz etkisi kadar, özellikle son sekiz yılda Ortadoğu'da yaşanan gelişmeler belirleyici

\footnotetext{
53 Alidad Mafinezam - Aria Mehrabi, Iran and Its Place Among Nations (Westport: Praeger Publishers, 2008), 68-69.

54 Frederic M. Wehrey, Sectarian Politics in the Gulf: From Iraq War to the Arab Uprisings (New York: Columbia University Press, 2014), 3-4.

55 Fürtig, Iran's Rivalry with Saudi Arabia, 42-49.

56 Keynoush, Saudi Arabia and Iran, 131-144.
} 
durumdadır. Her iki ülkenin de, birbirinin rağmına ve birbirinden 'rol çalarak' bölgede yatırım yaptığ 1 yerel aktörlerin varlığı ve etkinlikleri, tehlikeli gerginliği hızla tırmandırmaktadır. Bu gerginlik politikasının bir yansıması olarak, 11 Eylül saldırıları sonrası oluşan yeni bölge konjonktüründe; Ürdün Kralı Abdullah'ın 2004 Aralık ayında verdiği bir demeçte 'Sünni Arap ülkelerinin Şii hilali tarafından kuşatıldığını' söylemesi, ${ }^{57}$ ardından da M1sır Cumhurbaşkanı Hüsnü Mübarek' in 'Ortadoğu' da yaşayan Şii toplulukların kendi ülkelerinden ziyade İran'a bağlllık hissettiğini' belirtmesi, yeni dönemin Şiî-Sünnî ihtilafı paradigmasının yeniden inşa edilmesine hizmet etti. Her iki açıklamanın da Riyad'ın iki sadık Sünni müttefikinden gelmesi, ardından da başta ABD olmak üzere Batı kamuoylarında 'Şii Hilali' tehlikesine dikkat çekilmesi, var olan gerginliği farklı bir boyuta taşıdı. Nüfus ve mezheplere ilişkin oranlar kaynaklar arasında farklılık göstermekteyse de; İslam dünyasının kabaca \% 12-15'ini oluşturan Şiilerin, İran'daki ezici nüfuslarına (\%85-87 civarı) ilaveten, Irak’ta \%60-65, Lübnan'da \%25, Bahreyn'de \%60, Kuveyt'te \%20, Katar'da \%15, Yemen'de \%35-40 (Zeydi), Suriye'de \%10-12 (Nusayri), Suudi Arabistan'da \%10-15, BAE'de \%15-20 civarındaki oran1 ${ }^{58}$ bölgenin Sünni Arap yönetimlerinin (hatta zaman zaman konjonktüre bağlı olarak Türkiye'nin de) kaygılarını daha da artırdı. Bu Şii nüfusun tarihsel anlamda İran'daki Oniki İmam Şiasına mensup olması, İmamiyye halkası dışındaki Zeydi ve Nusayrilerin de siyasi ve askeri olarak İran'dan açık destek almaları, Tahran'ın nüfuz sahasının ulaştığı boyutlar açısından dikkat çekmektedir. ${ }^{59}$

2011'de başlayan Arap Baharı sürecinde Suriye'de ortaya çıkan protestolar, ülke içi Baas karşıtı mücadelenin (1993-2005 Çeçenistan örneğinde olduğu gibi) uluslararasılaştırılması ve yabancı savaş̧̧ılar eliyle 'çalınmasının' ardından, şehirlerin yerle bir edildiği, yüzbinlerce insanın hayatını kaybedip, milyonlarcasının mülteci durumuna düştüğü trajik bir boyuta ulaştı. Aradan geçen sekiz yılda Şam'daki baskıcı yönetim, iktidarı kay-

57 Simon Mabon, Saudi Arabia \& Iran: Soft Power Rivalry in the Middle East, (London: I.B. Tauris, 2013), 54

58 Mehmet Ali Büyükkara, "İslam Kaynaklı Mezheplerin Ortadoğu'daki Coğrafi Dağılımı ve Tahmini Nüfusları", e-makâlât Mezhep Araştırmalar,, VI, No.2 (Güz 2013): 321354, Adem Arıkan, "İslam Dünyasının Mezhep Haritası ve Nüfus Dağılımı”, Journal of Islamic Research, 29, No.2 (2018): 348-379.

59 Mehmet Akif Koç, Rekabetten Geleceğe: Türkiye-İran İlişkilerinin Güvenlik Boyutu (İstanbul: TASAM Yayınları, 2012),55-95. 
betmemesini büyük oranda, Rusya'nın hava desteği ve ABD'yi siyaseten dengelemesi kadar, İran öncülüğündeki Şii milisler ve Hizbullah'ın karada kontrolü ele almasına borçludur. Suriye sahasında, Suudi Arabistan'ın (diğer dış müttefikleriyle beraber) desteklediği gruplar, İran ve müttefiki Şii gruplara karşı başarısız oldu ${ }^{60}$ Riyad'ın geçtiğimiz aylarda, ABD'nin ülkeden çekilme tehdidine karşılık, Mısır'la birlikte Suriye'ye asker gönderme ve harekâta maddi destek sağlama söylemi ise, büyük bir ihtimalle mevcut konjonktürde kaybedilmiş vekâlet savaşının biraz daha uzamasından başka bir sonuç sağlamayacaktır.

Suriye'nin iki istikrarsız komşusu Irak ve Lübnan'da da benzer bir sonuç ortaya çıkmış durumdadır. Ülkedeki Sünni azınlığa dayanan Baasçı Saddam yönetimini uzun yıllar destekleyen Riyad'ın, ABD'nin işgalinin ardından yapılan seçimlerde, ülkenin üçte ikisini oluşturan Şiilerin yönetimi ele almasına karşılık tek yapabildiği, kendisiyle diyaloğa hazır bir Şii Başbakan'ın yönetime gelmesi için gayret göstermek ve var olan Sünni nüfuz sahasını tahkim etmeye çalışmak oldu. Suudi Arabistan'ın bu ümitsiz beklentisine karşıllk, uzun yıllar Irak Şiileriyle işbirliği yapmış olan İran'ın hem alternatifleri hem de manevra imkânlarının daha geniş olduğu ise aşikârdır. ${ }^{61}$ Üstelik dönem dönem ülke siyasetinde etki sahibi ve belirleyici olabilen Kürt ve Türkmenler üzerinde de İran'ın hareket alanı Riyad'a göre çok daha fazladır. ${ }^{62} 2018$ Mayıs ayında yapılan seçimlerde, Suriye yönetimine açık desteği ve İsrail karşıtı duruşuyla Lübnan içinde güç ve popülaritesini artıran Hizbullah'ın, Suudilerin desteklediği Hariri öncülüğündeki koalisyona karşı açık farkla birinci olması da, keza Tahran'ın Riyad'a üstün geldiği bir başka bölgesel zemini oluşturmaktadır.

İran ile Suudi Arabistan'ın açıkça bilek güreşine girdikleri bir başka bölge ülkesi olan Yemen'de ise, Veliaht Prens Muhammed bin Selman'in 2015'te göreve geldikten hemen sonra giriştiği askeri harekât ve yoğun bombard1man, Arap dünyasının en fakir bölgelerinden biri olan ülkede açlık ve sefaleti daha da artırdı. Buna rağmen, Riyad'ın desteklediği Cumhurbaşkanı

60 Christopher Phillips \& Morten Valbjørn, 'What is in a Name?': The Role of (Different) Identities in the Multiple Proxy Wars in Syria, Small Wars \& Insurgencies, 29:3, 414433.

${ }_{61}$ Mabon, Saudi Arabia \& Iran, 182-183; Keynoush, Saudi Arabia and Iran, 187-199.

62 Mehmet Akif Koç, “İran'ın Irak Kürdistan Bölgesel Yönetimi’nin (IKBY) Bağımsızlık Girişimlerine Bakışı”. International Journal of Kurdish Studies, 5 (2019): 359-362. 
Mansur Hadi’nin ülkenin büyük bir bölümü üzerinde kontrolü olmadığ1 gibi, kendisi de 2015 yılından beri Suudi Arabistan'da sürgünde yaşamaktadır. Riyad'ın, tüm askeri üstünlüğü ve hava bombardımanlarına rağmen, Yemen harekâtında uğradığı sonuç, çoğu uluslararası gözlemci tarafindan 'fiyasko' olarak tanımlanmaktadır. ${ }^{63}$ Buna karşılık, İran'dan askeri ve taktik stratejik destek de almakta olan Yemen Zeydileri, s1k sık füze ve drone saldırılarında bulunarak Riyad, BAE liman şehirleri ve diğer stratejik yerleşimlere mukabil saldırılar gerçekleştirmekte; bu durum 2019 Mayıs ayındaki saldırılarda da görüldüğü üzere, mevcut çatışma atmosferini hızla bölgesel bir savaşa dönüştürme tehlikesi taşımaktadır.

Filistin-İsrail ihtilafı ve bu bağlamda Filistinli gruplar üzerindeki nüfuz yarışı da iki ülkeyi son dönemde karşı karşıya getiren bir diğer ihtilaf noktasıdır. İran'ın 1979 Devrimi'nden sonra Filistin Davasına verdiği desteğin yanısıra, Hizbullah, Hamas, İslami Cihad gibi gruplar üzerinden İsrail'i askeri olarak da yıpratma ve güvenlik tehdidi oluşturma stratejisi büyük ölçüde başarıya ulaşmıştır. ${ }^{64}$ Buna karşılık, 1970'lerde Arap-İsrail savaşlarından dolayı en yakın müttefiki ABD'yi bile karşısına alan ve tarihi petrol boykotunu başlatan Suudi Arabistan'ın son yıllarda geldiği pasif nokta ise, Arap kamuoyundan dahi ciddi eleştiri almaktadır. Suud Veliaht Prensi Muhammed bin Selman'ın 2018 Nisan ayındaki ABD ziyaretinde bir araya geldiği Yahudi toplumu temsilcileriyle toplantıda söylediği iddia edilen ve son dönemdeki çizgisiyle de uyumlu olan 'Filistinliler çenesini kapatmalı ve kendilerine önerilen barış planını kabul etmeli' şeklindeki sözleri, bu politik savrulmanın ulaştı̆g 1 boyuta işaret etmektedir. Her ne kadar Kral Selman, sonradan oğlunun sözlerini düzeltse ve Filistin meselesinin Suudi Arabistan açısından çok önemli bir gündem maddesi olduğunu söylese de, ${ }^{65}$ Kudüs gündemi ve Washington-Tel Aviv-Riyad eksenindeki yakın

63 Ahmed Anwer Mohammed \& Ravichandran Moorthy, "Saudi-Iran Rivalry in the Middle East: Implication to National Security", Journal of Social Sciences and Humanities, 16, No.1 (2019): 1-13; Dilip Hiro, Cold War in the Islamic World: Saudi Arabia, Iran and the Struggle for Supremacy (New York: Oxford University Press, 2018), 307-311.

64 Trita Parsi, Treacherous Alliance: The Secret Dealings of Israel, Iran, and the US (New Haven: Yale University Press, 2007), 176-177.

65 Aiden Pink, "Palestinians Should 'Shut Up' or Make Peace, Saudi Crown Prince Told Jewish Leaders", Haaretz, 25 Nisan 2019, Erişim Tarihi: 5 Mayıs 2019, https:// www.haaretz.com/middle-east-news/palestinians/palestinians-should-shut-up-ormake-peace-said-saudi-crown-prince-1.6036624 Stephen Kalin, “After Son's Israel 
ilişkilerin de tesiriyle bu husustaki moral avantajın ve sahadaki dengelerin daha ziyade İran lehine olduğu değerlendirilmektedir.

Tahran-Riyad ilişkilerinde bir diğer varoluşsal ihtilaf konusu ise İran nükleer programı ve bununla bağlantılı olarak, 2015 yılında P5+1 ülkelerinin Tahran'la imzaladığı Kapsamlı Ortak Eylem Planı (JCPOA) anlaşmasının kırılgan dengesidir. 2016'da, Donald Trump'ın ABD'de Başkan seçilmesiyle tekrar tartışmaya açılan anlaşmaya, imzalandığı süreçte en fazla karş1 çıkan iki ülke, İran'dan algıladıkları güvenlik tehditlerinin bu anlaşmayla giderilmediğini savunan Suudi Arabistan ve İsrail olmuştu. ${ }^{66} \mathrm{Bu}$ bağlamda, son birkaç yılda ABD-İsrail-Suudi Arabistan üçgenindeki dengeler nükleer programdan çekilme kaynaklı risklerin yanısıra, Suriye ve Ortadoğu'da artan İran nüfuzu gerekçesiyle her an İran'a askeri bir saldırı olabileceği beklentisi yaratmaktadır. Bu çerçevede; Trump'ın göreve geldiğinde ilk ziyaretini Riyad'a yapması ve Suud Kralı-Mısır Cumhurbaşkanıyla görüşerek İran karşıtı sert açıklamalarda bulunması; ABD yönetiminde İran'la yapılan anlaşmaya bağlı kalmayı savunan Tillerson, McMaster gibi isimlerin görevden alınıp yerlerine açıkça İran'la savaşı savunan Pompeo, Bolton gibi sertlik yanlısı isimlerin getirilmesi; Riyad'dan sürekli duyulan İran'1 bölgede kaosun sebebi olarak işaret eden ve Hamaney'i Hitler'e benzeten yorumlar; İsrail'in sık s1k Suriye'de İran askeri hedeflerini vurmas1, İran bu ülkeden çıkmazsa Esad'ı düşürmekle tehdit etmesi, İran'ın ekonomik yaptırımlarla sürekli köşeye sıkıştırılması vd gelişmeler, İran karşıtı ciddi bir savaş ittifakının kurulmuş olduğunu, bu ittifakın İran'ı Suriye'de tahrik ederek/yanıt vermeye zorlayarak, nükleer program bağlantılı tazyik unsurlarıyla bir şekilde İran topraklarına askeri operasyon düzenlemek ve İran'la savaşmak niyetinde olduğuna dair yorumları artırmaktadır.

Gelinen noktada yukarıda zikredilen ikili, bölgesel ve uluslararası gelişmelerin zorlamasıyla İran ve Suudi Arabistan neredeyse savaşın eşiğine gelmiş olup; XX. yüzyılın son çeyreği ve XXI. yüzyılın ilk çeyreği itibariy-

Comments, Saudi King Reiterates Support For Palestine", Reuters, 25 Nisan 2019, Erişim Tarihi: 26 Nisan 2019, https:/uk.reuters.com/article/uk-israel-palestinianssaudi/saudi-king-reiterates-support-for-palestinians-after-israel-commentsidUKKCN1HA19Y

66 Ashish Kumar Sen, "Strange Bedfellows: Saudi Arabia, Israel Oppose Iran Nuclear Deal for Different Reasons”, Atlantic Council, Erişim Tarihi: 26 Nisan 2019, https:// www.atlanticcouncil.org/blogs/new-atlanticist/strange-bedfellows-saudi-arabiaisrael-oppose-iran-nuclear-deal-for-different-reasons 
le, Dilip Hiro'nun deyimiyle, “İslam Dünyası'nın Soğuk Savaşı” iki ülke arasında doğrudan ve dolaylı araçlar vasıtasıyla yeniden sahneye konmuş durumdadır. Bu bağlamda, Şankıti'nin (2016) naklettiği şu örnek olay, tarihsel hafizanın modern dönemdeki 'soğuk savaşa' nasıl yansıdığını ortaya koyması açısından önem taşımaktadır:

Amerikan işgali sonrasındaki iç çatışmalar döneminde, 2006 yılında, Irak'ın Samarra şehrinde bulunan (Şii İmamet silsilesindeki) XI. İmam Hasan el-Askeri'nin (ö. 260/874) türbesinin de içinde bulunduğu Askeriyye Camii'nin altın kubbesi bir terör saldırısı sonucu yıkıldığında, Şiilerin tepkisi çok sert olmuş ve mukabil bombalı saldırılar sonucunda çok sayıda Sünni Iraklı hayatını kaybetmişti. Tüm bu karşı1ıklı katliamların ortasında, Irak'ta yayınlanan bir radyo programında sunucunun, 'bu menfur saldırıların faili kim olabilir?' sorusuna cevaben, programa bağlanan bir dinleyicinin verdiği kendinden emin cevap, "Caminin kubbesini kimin yıktığını biliyorum: Ebu Bekir ve Ömer yıktı" şeklinde olmuştu. ${ }^{67}$ Nitekim, günümüzde olduğu gibi, muhtemelen gelecekteki bölgesel savaşlarda da bu tarihsel ayrılıkların yeniden hatırlanıp, kitlelerin karşı karşıya gelmelerinde bu dinamiklerin yeniden istismar edilmesi şaşırtıcı olmayacaktır. Diğer taraftan, bu cevap aslında, toplumların müşterek hafızalarında tarihin ağır yükünün nasıl taşınmaya zorlandığının da açık bir göstergesi niteliğindedir.

\section{Sonuç}

XXI. yüzyılın başında, Ortadoğu coğrafyasında yeniden sert bir ivme kazanan Şî̂-Sünnî ihtilafının esasen uzun bir tarihi geçmişi ve kendisini bir türlü unutturmayan bir arkaplanı bulunmaktadır. Hulefâ-i Râşidîn döneminde başlayan ilk ayrılıkların bilahare kanlı çatışmalara dönüşmesi ve Şii siyasi / toplumsal çevrelerin Emeviler döneminde sert bir şekilde bastırılmasıyla başlayan ilk dönem ihtilafları, Abbasiler devrinde farklı bir boyut kazanmıştır. Abbasilerin iktidara geliş sürecinde yaşanan işbirliği ve takip eden dönemdeki tasfiye sürecine ilaveten, bilhassa $X$ ve XI. yüzyllarda Bağdat'ta egemen duruma gelen Deylem (Kuzey İran) kökenli Büveyhiler zamanında İmamiyye Şiası gelişip serpilme imkânı bulmuş, asırlar süren baskı döneminin ardından fikhi ve toplumsal düzlemde kurumsallaşabil-

${ }^{67}$ Şankıtî, Sünni-Şii İlişkileri, 9-10. 
me, kendi teorisyenlerini yetiştirebilme zeminine kavuşmuştur. Bu dönemde, İbn Haldun'un da tespit ettiği üzere, Şiilerin karşısında buldukları ası1 rakip, genel bir 'Sünni bloktan' ziyade, daha katı ve Şia karşııtı söylemiyle Hanbeliler olmuştur.

Aynı dönemde, Mısır'daki İsmailî Fatımi Devleti'nin varlığıyla birlikte değerlendirince, Haçlı Seferleri öncesi döneme damga vuran bu ayrım, Moğol saldırıları sürecinde kesintiye uğrasa da, Safevi-Osmanlı rekabeti bağlamında tekrar kendisini göstermiştir. Bilhassa Safeviler bağlamında dikkat çekici bir husus da, Şii kimliğin İran'da hâkim bir konuma gelmesi ve bu suretle ortaya çıkan dini-politik sentezin günümüzdeki Şiilik inanç ve pratiğinin büyük oranda altyapısını oluşturmasıdır. Nihayetinde, XVIII. yüzyılın son döneminde Necd'de ortaya çıkan İbn Abdülvahhab liderliğindeki Vahhabiliğin siyasi ve kültürel kodları da, Şiilik karşıtı bir çizgi takip etmiş, İbn Teymiyye'nin görüşleriyle beslenen bir hat boyunca günümüze kadar bu çizgiyi muhafaza ve müdafaa etmiştir.

Günümüzde kimi zaman açıktan, ancak çoğunlukla örtülü olarak (proxy wars) Körfez bölgesinde ve Ortadoğu'nun genelinde sık sık karşıya gelen, bölgenin siyasi ve askeri açıdan güçlü iki ülkesi, İran ve Suudi Arabistan arasında yaşanan güç çatışması, sadece hâlihazırda geçerli saiklerle açıklanamayacak ölçüde karmaşık bir dini, mezhepsel ve kültürel arkaplana dayanmaktadır.

Bu bağlamda, gerek İran gerekse Suudi Arabistan'ın hâlihazırdaki iç siyasi, sosyolojik ve kültürel kodlarının yanısıra, dış politika yönelimleri ve bölgesel / uluslararası tehdit algıları da büyük ölçüde Konstrüktivist temelli kimlik siyasetine ve inşa edilen kimlik tanımlamalarına göre belirlenmektedir. İran açısından Şiiliğin ihtiva ettiği tarihi ve kültürel arkaplan, uzun ve sorunlu geçmiş boyunca Şiiliğin ötekisi olarak değerlendirilen Sünni kimliğinde kendisine rekabet edeceği bir dış düşman bulmaktadır. Bununla birlikte, yekpare bir bütünlük arz etmeyen Sünni dünya içerisinde, bilhassa Vahhabilik, 1979 İran Devrimini takip eden kırk yıllık süreçte asıl 'öteki' olarak temayüz etmiş durumdadır. Nitekim özellikle 2011 sonrası Arap İsyanları sürecinde bir kez daha açıklığa kavuştuğu üzere, başını Suudi Arabistan (ve bir ölçüye kadar BAE’nin) çektiği Selefi/Vahhabi güç merkezi, İran'ın bölgedeki başlıca rakibi durumuna gelmiştir. Diğer taraftan, Suudi Arabistan açısından da İran, bölgede asıl önemli tehdit unsuru olarak değerlendirilmekte; İran Devrimi'nin hemen ardından 1981'de kurulan 
Körfez İşbirliği Konseyi (KİK) örneğinden başlayarak günümüze değin, dönemsel yumuşama belirtileri görülse de, Riyad ve Tahran arasında hemen her dönemde gergin/ihtiyatlı ilişkiler ve sıcak çatışmaya evrilebilecek ihtilaflar yaşanmaktadır.

Bu bağlamda, İran-Suudi Arabistan ilişkileri ve Şiî-Sünnî ihtilafı bağlamında dikkat çekici bir diğer olgu da, yaklaşık bin yıl önce, X ve XI. asırlarda önemli ölçüde katılaşıp mezhepler arası çekişme halini alan bu ihtilafın, günümüzdeki 'soğuk savaş' döneminde de yine aynı coğrafyada, Irak-Suriye-İran-Arabistan bölgesinde kendisine yeniden yaşam alanı bulabilmesidir.

Sonuç olarak, günümüzde aldığı şekil itibariyle, iyice sertleşen her iki taraftaki dışlayıcı yaklaşımın farklı boyutlarda ve çeşitli argümanlarla sürekli tazelenip yenilenmesi, sözkonusu ihtilafların uzun bir süre daha bölgenin geleceği üzerinde belirleyici olmasını netice verecektir. Her ne kadar, benzer şekilde, yüzyıllar boyunca birbiriyle dini ve politik saiklerle savaşmış olan Fransız ve Alman milletlerinin günümüzde tarihin en başarılı entegrasyon süreçlerinden $\mathrm{AB}$ 'ye önderlik etmeleri bir realite olarak önümüzde durmaktaysa da, öngörülebilir gelecekte Ortadoğu'da benzer bir normalleşme ve entegrasyon sürecine işaret edebilecek ümitvâr bir tablo çizebilmek güç görünmektedir.

\section{Kaynakça}

Azimli, Mehmet. Babek: Bir Direniş̧̧i. Konya: Çizgi Kitabevi, 2013.

Arıkan, Adem. "İslam Dünyasının Mezhep Haritası ve Nüfus Dağılımı”. Journal of Islamic Research, 29, No.2 (2018): 348-379.

Bağdadi, Ebu Mansur Abdulkahir b. Tahir b. Muhammed. El-Fark Beyne'lFirak (Mezhepler Arasındaki Farklar). Trc. Ethem Ruhi Fiğlalı. Ankara: Türkiye Diyanet Vakfı Yayınları, 1991.

Bozan, Metin. İmamiyye'nin İmamet Nazariyesinin Teşekkül Süreci. İstanbul: İSAM Yayınları, 2009.

Büyükkara, Mehmet Ali. İmamet Mücadelesi ve Haşimoğulları. İstanbul: Rağbet Yayınları, 1999. 
Büyükkara, Mehmet Ali. "İslam Kaynaklı Mezheplerin Ortadoğu'daki Coğrafi Dağılımı ve Tahmini Nüfusları”. E-makâlât Mezhep Araştırmala$r l$, VI, No.2 (Güz 2013): 321-354

Çelenk, Mehmet. Safeviler Döneminin Şî̂-Sünnî İlişkileri Üzerindeki Etkisi. E-Makalât Mezhep Araştırmaları Dergisi, VI, No.2 (Güz 2013): 63-85.

Daftary, Farhad. Şii İslam Tarihi. Trc. Ahmet Fethi. İstanbul: Alfa Kitap, 2016.

DeLong-Bas, Natana J. Wahhabi Islam-From Revival and Reform to Global Jihad. London: I.B. Tauris, 2007.

Fürtig, Henner. Iran's Rivalry with Saudi Arabia Between the Gulf Wars. Reading: Ithaca Press, 2002.

Garthwaite, Gene R.. İran Tarihi: Pers İmparatorluğundan Günümüze. Trc. Fethi Aytuna. İstanbul: İnkılap Kitabevi, 2011.

Gibb, Hamilton A.R. "The Caliphate and the Arab States" A History of the Crusades, ed. M.W. Baldwin. 81-98. Wisconsin: The University of Wisconsin Press, 1969.

Güner, Ahmet. Büveyhilerin Sii-Sünni Siyaseti. İzmir: Tibyan Yayınc1lı, 1999.

Güner, Ahmet ve Azimli, Mehmet. "Büveyhiler: Abbasiler'in Başkenti Bağdat’ta Hüküm Süren İran Kökenli Şii Bir Hanedan". İslam Tarihi ve Medeniyeti Külliyatı, Cilt 7 (Abbasiler Döneminde Kurulan Devletler). Ed. İsmail Hakkı Atçeken ve Mustafa Demirci. İstanbul: Siyer Yayınları, 2018. Hinnebusch, Raymond. "Foreign Policy in the Middle East". The Foreign Policies of Middle East States. Ed. Hinnebusch, Raymond and Ehteshami, Anoushiravan. 1-36. Boulder: Lynne Reinner, 2014

Hiro, Dilip. Cold War in the Islamic World: Saudi Arabia, Iran and the Struggle for Supremacy. New York: Oxford University Press, 2018.

Hodgson, Marshall G.S. "How did the Early Shî'a become Sectarian?", Journal of the American Oriental Society, 75, No. 1 (Jan-Mar. 1955): 1-13 İbn Hazm, Ebu Muhammed Ali b. Ahmed b. Said b. Hazm. el-Fasl fi'lMilel ve'l-Ehva've'n-Nihal (Dinler ve Mezhepler Tarihi). Trc. Halil İbrahim Bulut. İstanbul: Türkiye Yazma Eserler Kurumu Başkanlığg, 2017. 
Ibn Haldun. Tarikh Ibn Khaldun. Beirut: Dar Al-Qalam, 1984.

Ibn al-Jawzi, Abd al-Rahman. Al-Muntazam fi Tarikh al-Mulûk ve'l-Umem. Beyrut: Dar Şadir, 1939.

İğde, Muhyettin. "Selefiliğin Tarihi Arka Planı. e-Makalat Mezhep Araştırmaları Dergisi, 8 , No.2 (Nisan 2016): 151-181.

İzzeti, İzzetullah. İran ve Bölge Jeopolitiği. Trc. Hakk1 Uygur. İstanbul: Küre Yayınları, 2005.

Kartaloğlu, Habib. “İmamiyye'de Ahbarî-Usulî Farklılaşması: Şeyh Saduk ve Şeyh Müfid Örneği”. Sakarya Üniversitesi Illahiyat Fakültesi Dergisi, XIII, Say1: 24 (2011/2): 193-216.

Kartaloğlu, Habib. "Şî̂-Usulî Düşüncenin Ortaya Çıkış Sebepleri Üzerine Mülahazalar". Sakarya Üniversitesi Illahiyat Fakültesi Dergisi, XVIII, Say1: 33 (Haziran 2016): 75-90.

Kâtip, Ahmet. Nedenleri Tarihte Kalmış Siyasi Ayrılık: Sünnilik-Şiilik. Trc. Muharrem Tan. İstanbul: Mana Yayınları, 2013.

Keynoush, Banafsheh. Saudi Arabia and Iran: Friends or Foes? New York: Palgrave Macmillan, 2016.

Koç, Mehmet Akif. Rekabetten Geleceğe: Türkiye-İran Illişkilerinin Güvenlik Boyutu. İstanbul: TASAM Yayınları, 2012.

Koç, Mehmet Akif. “İran'ın Irak Kürdistan Bölgesel Yönetimi’nin (IKBY) Bağımsızlık Girişıimlerine Bakışı”. International Journal of Kurdish Studies, 5 (2019): 359-362.

Kummi el-Eş'ari, Sa'd b. Abdullah Ebu Halef - Nevbahti, Ebu Muhammed Hasan b. Musa. Kitabü'l-Makalat ve'l-Fırak / Fıraku'ş-Şia (Şii Fırkalar). Trc. Hasan Onat / Sabri Hizmetli / Sönmez Kutlu / Ramazan Şimşek. Ankara: Ankara Okulu Yayınları, 2004.

Mabon, Simon. Saudi Arabia \& Iran: Soft Power Rivalry in the Middle East. London: I.B. Tauris, 2013.

Mafinezam, Alidad - Mehrabi, Aria. Iran and Its Place Among Nations. Westport: Praeger Publishers, 2008.

Mohammed, Ahmed Anwer - Moorthy, Ravichandran. "Saudi-Iran Rivalry in the Middle East: Implication to National Security". Journal of Social Sciences and Humanities Vol. 16, No.1 (2019), 1-13. 
Mutahhari, Murtaza. Ehl-i Beyt Imamlarinin Siyasi Tutumlarl. Trc. Cafer Bendiderya. İstanbul: Kevser Yayınları, 2007.

Nasr, Seyyed Hossein. Islam - Religion, History, and Civilization. New York: HarperCollins Publishers, 2003.

Özler, Mevlüt. İslâm Düşüncesinde 73 Fırka Kavramı. İstanbul: Nûn Yayınları, 1996.

Parsi, Trita. Treacherous Alliance: The Secret Dealings of Israel, Iran, and the US. New Haven: Yale University Press, 2007.

Philips, Christopher - Valbjørn, Morten. 'What is in a Name?': The Role of (Different) Identities in the Multiple Proxy Wars in Syria. Small Wars \& Insurgencies, 29:3, 414-433

Said, Edward. Orientalism. London: Penguin Books, 1977.

Sallabi, Ali Muhammed. Zengiler Dönemi - İslami İdarenin Yeniden Hâkim Kılınması. Trc. Turgut Akyüz. İstanbul: Ravza Yayınları, 2014.

Saud, Faisal bin Salman. Iran, Saudi Arabia and the Gulf: Power Politics in Transition. London: I.B. Tauris, 2003.

Söylemez, M. Mahfuz. "İlk Dönem İslam Tarihi Kaynaklarına Göre Cahiliye Araplarında Ahiret İnanc1". Milel ve Nihal, 13 , No.1 (2016): 71-109.

Şahin, Hanifi. “Abbasilerin Son Dönemlerinden İlhanlıların Yıkılışına Kadarki Süreçte Şiî-Sünnî İlişkileri”. Ortadoğu'nun Geleceği Açısından Şiî-Sünnî İlişkileri Sempozyumu Bildirileri (Çorum, 27-29 Eylül 2013). Ed. Mesut Okumuş - Cemil Hakyemez. 35-52. Ankara: Çorum Belediyesi Kültür Yayınları, 2014.

Şankıtî, Muhammed b. El-Muhtar. Haçlı Seferlerinin Etkisi Altında Sün$n i$ - Şii İlişkileri. Trc. İdris Çakmak. İstanbul: İlimyurdu Yayıncılık, 2016.

Şehristani, Muhammed b. Abdülkerim b. Ahmed. el-Milel ve'n-Nihal (Dinler, Mezhepler ve Felsefi Sistemler Tarihi). Trc. Mustafa Öz. İstanbul: Litera Yayınc1lik, 2008.

Şeriati, Ali. Ali Şiası Safevi Şiası. Trc. Hicabi Kırlangıç. Ankara: Fecr Yayınevi, 2009.

Şeriati, Ali. İran ve İslam. Trc. Kenan Çamurcu. Ankara: Fecr Yayınevi, 2012. 
Tabatabai, Sayyid Muhammad Husayn. Shiite Islam. Albany: State University of New York Press, 1975.

Teixidor, Javier. The Pagan God: Popular Religion in the Greco-Roman Near East. New Jersey: Princeton University Press, 1977.

Topaloğlu, Fatih. "Şia'nın Oluşumunda İran Kültürünün Etkisi”. Yayınlanmamış Doktora Tezi, Dokuz Eylül Üniversitesi Sosyal Bilimler Enstitüsü Temel İslam Bilimleri Anabilim Dalı, 2010.

Trofimov, Yaroslav. 1979 Kâbe Baskını: Kutsal Mekânda Ayaklanma. Trc. Özlem Özarpacı. İstanbul: İyidüşün Yayınları, 2016.

Türcan, Talip. "Şûra". Türkiye Diyanet Vakfi İslam Ansiklopedisi. 39, İstanbul: TDV Yayınları, 2010.

Watt, W.M. Muhammad's Mecca: History in the Qur'an. Edinburgh: Edinburgh University Press, 1988.

Wehrey, Frederic M. Sectarian Politics in the Gulf: From Iraq War to the Arab Uprisings. New York: Columbia University Press, 2014.

Wellhausen, Julius. İslamiyet'in İlk Devrinde Dini - Siyasi Muhalefet Partileri. Trc. Fikret Işıltan. Ankara: Türk Tarih Kurumu Yayınevi, 1996.

Yıldırım, Deniz. Ortadoğu'da Vahhabi-Şii Mücadelesi, TESAM Akademi Dergisi, (Ocak 5, No.1 (2018): 63-95.

Yıldırım, Ramazan. "Sünni Siyaset Düşüncesinin Tarih İçindeki Gelişimi ve Etkinliğii”. İstanbul Üniversitesi İlahiyat Fakültesi Dergisi, 24, (2011):5-24.

Yıldız, Harun - Maden, Ferhat. "Büveyhîler Dönemi Şî̂ Düşünürleri”". e-Makalat Mezhep Araştırmaları Dergisi 10, No. 2 (Aralık 2017): 269314.

Yönem, Ahmet. "Şiî-Sünnî İlişkileri Bağlamında Günümüz Selefiliğì". Ortadoğu'nun Geleceği Açısından Şî̂-Sünnî İlişkileri Sempozyumu Bildirileri (Çorum, 27-29 Eylül 2013). Ed. Mesut Okumuş - Cemil Hakyemez. 119-138. Ankara: Çorum Belediyesi Kültür Yayınları, 2014. 


\section{İnternet Kaynakları}

Kalin, Stephen. "After Son's Israel Comments, Saudi King Reiterates Support For Palestine", Reuters, Erişim tarihi: 25 Nisan 2019. https:// uk.reuters.com/article/uk-israel-palestinians-saudi/saudi-king-reiteratessupport-for-palestinians-after-israel-comments-idUKKCN1HA19Y.

Onat, Hasan. "XVIII. Asırda Sünni- Şii İttifak Arayışları Üzerine”. Erişim Tarihi: 27 Şubat 2019 http://www.hasanonat.net/index.php/93-xviii-asrda-suenni-sii-ittifak-aray-slar-uezerine\#.

Pink, Aiden. "Palestinians Should 'Shut Up' or Make Peace, Saudi Crown Prince Told Jewish Leaders", Haaretz, Erişim Tarihi: 25 Nisan 2019, https://www.haaretz.com/middle-east-news/palestinians/palestiniansshould-shut-up-or-make-peace-said-saudi-crown-prince-1.6036624 .

Sen, Ashish Kumar. "Strange Bedfellows: Saudi Arabia, Israel Oppose Iran Nuclear Deal for Different Reasons", Atlantic Council. Erişim Tarihi: 26 Nisan 2019, https://www.atlanticcouncil.org/blogs/new-atlanticist/ strange-bedfellows-saudi-arabia-israel-oppose-iran-nuclear-deal-fordifferent-reasons. 